\title{
INFLUENCE OF RAW MEAT NATURAL BACKGROUND FLORA ON GROWTH OF ESCHERICHIA COLI O157:H7 IN GROUND BEEF
}

\author{
Susana M.I. Saad; Bernadette D.G.M. Franco* \\ Universidade de São Paulo - USP, Faculdade de Ciências Farmacêuticas, Departamento de Alimentos e \\ Nutrição Experimental. São Paulo, SP, Brasil
}

Submitted: April 04, 1999; Returned to authors for corrections: July 02, 1999; Approved: July 07, 1999.

\begin{abstract}
Escherichia coli $\mathrm{O} 157: \mathrm{H} 7$ is a foodborne pathogen of increasing importance. It has been involved in several threatening outbreaks, most of them associated with meat products. In this study, the influence of some bacteria from the natural background flora of raw meat over E.coli $\mathrm{O} 157: \mathrm{H} 7$ in ground beef stored under refrigeration and at room temperature was evaluated. Different levels of E.coli O157:H7 $\left(10^{1}-10^{2}, 10^{3}-10^{4}\right.$ and $10^{6}-10^{7} \mathrm{CFU} / \mathrm{g}$ ), inoculated in ground beef samples, were challenged with strains of non-pathogenic E.coli, Pseudomonas putida or Leuconostoc sp. Growth of the pathogen was monitored using standard cultural methods and an ELISA-type rapid method. Nonpathogenic E.coli, Pseudomonas putida and Leuconostoc sp. did not affect growth of E.coli $\mathrm{O} 157: \mathrm{H} 7$ in ground beef, both under refrigeration and at room temperature. Based on these findings, the low occurrence of E.coli $\mathrm{O} 157: \mathrm{H} 7$ in raw meat may not be attributed to antagonistic effects of bacteria from the natural background flora.
\end{abstract}

Key words: Escherichia coli $\mathrm{O} 157: \mathrm{H} 7$, antagonism, ground beef

\section{INTRODUCTION}

Enterohemorrhagic Escherichia coli is a foodborne pathogen of increasing importance. It was identified as a human pathogen in 1982, when $E$. coli serotype O157:H7 was associated with two outbreaks of hemorrhagic colitis (20). Since then, many outbreaks have been reported, culminating in 1996 in Japan with a foodborne outbreak that affected at least 6,309 children from 62 Sakai schools $(9,23)$.

Most confirmed E. coli O157:H7 outbreaks have been associated with the consumption of undercooked ground beef and less frequently, other types of foods like unpasteurized milk and apple cider (6).
Geographically, the focus of attention on E. coli O157:H7 has been largely on the North American continent. However, recent reports reveal that E. coli O157:H7 and other serotypes of enterohemorrhagic $E$. coli are responsible for human disease in other parts of the world as well. The apparent geographic clustering of E.coli O157:H7 may be due to awareness by physicians and testing laboratories (13, 24). Some reports have addressed on infections caused by Shiga-toxin producing E. coli and its presence in food in developing countries like Argentina, Chile and Thailand (5, 15, 22). Moreover, in Argentina E.coli serotype O157:H7 has been associated with 2 to $18 \%$ hemolytic uremic syndrome

\footnotetext{
* Corresponding author. Mailing address: Universidade de São Paulo, Faculdade de Ciências Farmacêuticas, Av. Prof. Lineu Prestes, 580, Bloco 14, CEP 05599-970, São Paulo, SP, Brasil. Fax (+5511) 815-4410, E-mail: bfranco@usp.br
} 
(HUS) patients and with 4.5 to $7 \%$ of children with bloody diarrhea (14).

So far, there is no report on occurrence of foodborne outbreaks due to Shiga-toxin producing E.coli in Brazil. Even the involvement of this pathogen in human cases of hemorrhagic colitis in this country is not known. Gomes et al., 1994, observed that Shiga-toxin producing E.coli was present in only $0.4 \%$ of children diarrheic stool samples, but none of the isolated strains was $\mathrm{O} 157: \mathrm{H} 7$ (10). The occurrence of E.coli $\mathrm{O} 157: \mathrm{H} 7$ or of other Shiga-toxin producing E.coli in cattle has also been very low (3).

Many explanations for the low occurrence of E.coli $\mathrm{O} 157: \mathrm{H} 7$ in raw meat may be considered. Studies showed that the carriage of E.coli O157:H7 in cattle is transient and seasonal and the prevalence of this pathogen in animals is low $(1,2)$. Besides this, interactions between microorganisms in raw meat are believed to be important in the selection of the microflora (7). Antibacterial activity of lactic acid bacteria (LAB) and Pseudomonas spp. over other microorganisms is well known $(4,17)$.

This study was conducted to observe possible antagonism between bacteria that are part of the background flora of raw meat and E. coli $\mathrm{O} 157: \mathrm{H} 7$ in ground beef samples kept under refrigeration and at room temperature. The study was carried out through challenge tests done with strains of nonpathogenic E.coli, Leuconostoc sp. and Pseudomonas sp. isolated from Brazilian raw meat.

\section{MATERIALS AND METHODS}

\section{Bacterial strains}

Escherichia coli O157:H7 strain EDL 933 was isolated from a hamburger outbreak (17). Nonpathogenic Escherichia coli, Pseudomonas putida and Leuconostoc sp. were isolated from Brazilian fresh raw meat products, purchased in local supermarkets of the city of São Paulo, Brazil.

The E.coli strain selected for this study was isolated using methods recommended by APHA (12) and characterized as non-pathogenic using DNA probes (16). The Pseudomonas putida strain was isolated using cetrimide-fucidin-cephaloridine agar (CFC agar - pseudomonads agar base type CM 559 with selective suplement SR 103; Oxoid), incubated at $30^{\circ} \mathrm{C}$ for 48 hours, and identified as Ps. putida using the VITEK system (bio-Meriéux). The Leuconostoc sp. strain was isolated using MRS agar (MRS broth plus $1.5 \%$ agar) for lactic acid bacteria, with incubation at $30^{\circ} \mathrm{C}$ for 48 hours, and identified as Leuconostoc sp. according to Schillinger and Lücke, 1987 (21).

\section{Preparation of meat}

Samples of bovine semitendinosus muscle were purchased in local supermarkets of the city of São Paulo, Brazil. Under aseptic conditions, the external layer (approximately $0.5 \mathrm{~cm}$ thick) of the muscle was removed and internal portions were grounded in a sterile meat grinder. The ground meat was divided into portions of $25 \mathrm{~g}$ in sterile plastic bags and kept frozen until used.

\section{Preparation of cultures}

The E. coli $\mathrm{O} 157: \mathrm{H} 7$ and the non-pathogenic $E$. coli strains were cultivated in TSB at $35^{\circ}-37^{\circ} \mathrm{C}$ for the time needed to reach $10^{8}-10^{9} \mathrm{CFU} / \mathrm{ml}$, determined through a spectrophotometric calibration curve. The Ps. putida and the Leuconostoc sp. strains were grown in TSB at $25^{\circ} \mathrm{C}$ and in MRS broth at $30^{\circ} \mathrm{C}$, respectively, for the time needed to reach $10^{8} \mathrm{CFU} / \mathrm{ml}$, also established through a spectrophotometric calibration curve. The bacterial cultures were serially diluted in $0.1 \%$ peptone water and $0.1 \mathrm{ml}$ of each dilution was plated onto TSA or MRS agar plates (MRS broth plus 1.5\% agar), for determination of the exact number of $\mathrm{CFU} / \mathrm{ml}$.

\section{Challenge tests}

Portions of $25 \mathrm{~g}$ of ground beef were inoculated with $2.5 \mathrm{ml}$ of the E. coli $\mathrm{O} 157: \mathrm{H} 7$ and the challenge cultures, using proper dilutions in order to get the following combinations:

- E. coli $\mathrm{O} 157: \mathrm{H} 7\left(0,10^{1}-10^{2}, 10^{3}-10^{4}\right.$ or $10^{6}-10^{7}$ $\mathrm{CFU} / \mathrm{g})$ and non-pathogenic E. coli $\left(0,10^{1}-10^{2}\right.$, $10^{3}-10^{4}$ or $10^{6}-10^{7} \mathrm{CFU} / \mathrm{g}$ );

- E. coli $\mathrm{O} 157: \mathrm{H} 7\left(0,10^{1}-10^{2}, 10^{3}-10^{4}\right.$ or $10^{6}-10^{7}$ $\mathrm{CFU} / \mathrm{g})$ and Pseudomonas putida $\left(0,10^{3}-10^{4}\right.$ or $\left.10^{6}-10^{7} \mathrm{CFU} / \mathrm{g}\right)$

- E. coli $\mathrm{O} 157: \mathrm{H} 7\left(0,10^{3}-10^{4}\right.$ or $\left.10^{6}-10^{7} \mathrm{CFU} / \mathrm{g}\right)$ and Leuconostoc sp. $\left(0\right.$ or $\left.10^{6}-10^{7} \mathrm{CFU} / \mathrm{g}\right)$.

Six equal samples were prepared for each inoculation level and combination. After 
homogenization of the inoculated meat samples by hand massaging of the plastic bags, four samples were kept under refrigeration $\left(8,5^{\circ} \mathrm{C}\right)$ and analyzed after 24, 48, 72 and 96 hours. The two remaining samples were kept at room temperature $\left(25^{\circ} \mathrm{C}\right)$ and analyzed after 24 and 48 hours. Negative controls, consisting of non-inoculated meat portions and of meat portions inoculated with only one of the microorganisms at each inoculation level, were also included.

\section{Analysis of inoculated meat samples}

Each ground beef sample was homogenized with $225 \mathrm{ml}$ of $0.1 \%$ peptone water in a Stomacher (Seward Medical Ltd.) and subsequent decimal dilutions were made using the same diluent. Portions of $0.1 \mathrm{ml}$ of each dilution were plated onto MacConkey-sorbitol agar (MCS, Difco) for enumeration of $E$. coli $\mathrm{O} 157: \mathrm{H} 7$ (sorbitol negative colonies) and non pathogenic $E$. coli (sorbitol positive colonies), onto cetrimide-fucidin-cephaloridine agar (CFC agar, Oxoid) for enumeration of Pseudomonas sp., or onto MRS agar (MRS broth plus $1.5 \%$ agar) for enumeration of lactic acid bacteria. The temperature and time of incubation for MCS agar was $35-37^{\circ} \mathrm{C}$ for $18-24$ hours, for $\mathrm{CFC}$ agar, $25^{\circ} \mathrm{C}$ for 48 hours and for MRS agar, $30^{\circ} \mathrm{C}$ for 48 hours. Colonies of E. coli $\mathrm{O} 157: \mathrm{H} 7$ on MacConkey-sorbitol agar were identified using suitable biochemical (glucose, lactose and sorbitol fermentation, production of gas, $\mathrm{H}_{2} \mathrm{~S}$, indol, urease and lysine descarboxilase and motility) and serological tests, according to Ewing, 1986 (7) and Toledo et al., 1982a,b $(25,26)$.

Enumeration of $E$. coli (non-pathogenic) was also performed on Petrifilm ${ }^{\mathrm{TM}} \mathrm{EC}$ plates (3M Microbiology, St. Paul, MN), with incubation for $18-24$ hours at $35^{\circ}-37^{\circ} \mathrm{C}$. For the enumeration of $E$. coli $\mathrm{O} 157: \mathrm{H} 7$, the Petrifilm ${ }^{\mathrm{TM}}$ kit HEC ( $3 \mathrm{M}$ Microbiology, St. Paul, MN) was used. This kit is based in a ELISA-type test, carried out with colonies grown on Petrifilm EC plates. The colonies are transfered from the plate to a reactive disc and O157:H7 antigens, if present, are used to capture enzyme-labeled anti-O157 antibodies (i.e., conjugate) in the first development step. The antibody location is detected in the second development step when the bound enzyme converts an identifying substrate to a permanent black spot on the disc. Each spot indicates an 0157:H7 presumptive-positive colony.

\section{RESULTS AND DISCUSSION}

Figs. 1a and $1 \mathrm{~b}$ illustrate the growth of $E$. coli O157:H7 in the samples kept under refrigeration and at room temperature, respectively, when the inoculation level of both E. coli $\mathrm{O} 157: \mathrm{H} 7$ and the challenging microorganisms was $10^{6}-10^{7} \mathrm{CFU} / \mathrm{g}$. When $E$. coli $\mathrm{O} 157: \mathrm{H} 7$ was inoculated individually in the meat samples and kept under refrigeration (Fig. 1a), the counts remained relatively constant throughout the 96 hours of experiment. A similar observation occurred when the other competing microorganisms were also present. At room temperature (Fig. 1b), the counts of all microorganisms increased similarly and were almost identical to that of control treatments in which $E$. coli $\mathrm{O} 157: \mathrm{H} 7$ was alone.

The curves in Fig. 1a and $1 \mathrm{~b}$ are almost coincident, presenting counts that didn't change significantly during the experiment.
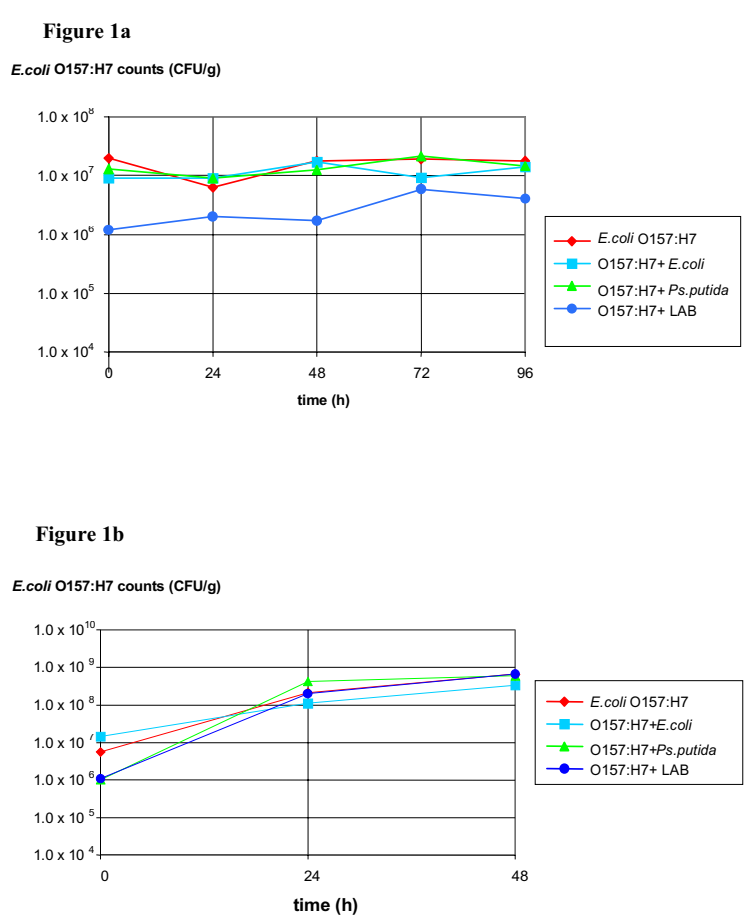

Figures 1a and 1b - Counts of E. coli $\mathrm{O} 157: \mathrm{H} 7$ in ground meat samples inoculated with E. coli $\mathrm{O} 157: \mathrm{H} 7$ and non-pathogenic $E$. coli, Pseudomonas spp. (Ps. putida) or lactic acid bacteria (LAB - Leuconostoc sp.), using an inoculation level of $10^{6}-10^{7} \mathrm{CFU} / \mathrm{g}$. $\mathbf{1 a}=$ meat samples kept under refrigeration; $\mathbf{1 b}=$ meat samples kept at room temperature. 
When the intermediate inoculation levels of $10^{3}-10^{4} \mathrm{CFU} / \mathrm{g}$ for E. coli $\mathrm{O} 157: \mathrm{H} 7$ and $10^{6}-10^{7} \mathrm{CFU} /$ $\mathrm{g}$ for the challenging microorganism was considered (Figs. 2a and 2b) some differences in the growth curves were noted. In Fig. $2 a$, they were due to variations in the number of CFU/g of E. coli $\mathrm{O} 157: \mathrm{H} 7$ in the inoculum. However, the counts after 96 hours were very similar to the initial ones. In Fig. $2 b$, a lower count of $E$. coli $\mathrm{O} 157: \mathrm{H} 7$ in the presence of non-pathogenic $E$. coli was observed at 24 hours, probably caused by difficulties to enumerate low numbers of colonies of the pathogen in the presence of high number of colonies of non-pathogenic $E$. coli. These difficulties increased when the lowest inoculation level $\left(10^{1}-10^{2} \mathrm{CFU} / \mathrm{g}\right)$ was assayed and results were not considered.

These results suggest that the presence of nonpathogenic E. coli, Pseudomonas putida or Leuconostoc sp. did not interfere with the growth or survival of $E$. coli $\mathrm{O} 157: \mathrm{H} 7$ in ground beef samples kept under refrigeration or at room temperature,

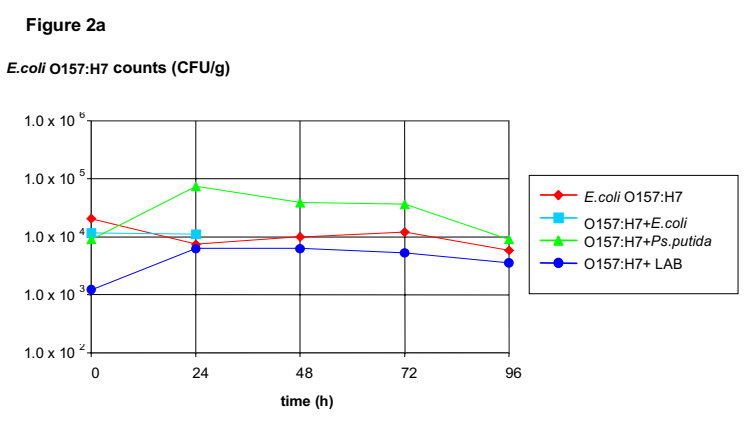

Figure 2b

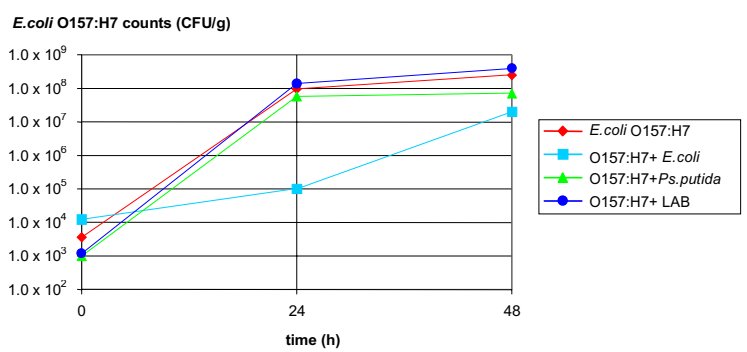

Figures 2a and 2b - Counts of E. coli $\mathrm{O} 157: \mathrm{H} 7$ in ground beef samples inoculated with $E$. coli $\mathrm{O} 157: \mathrm{H} 7$ and non-pathogenic $E$. coli, Pseudomonas spp. (Ps. putida) or lactic acid bacteria (LAB - Leuconostoc sp.), using an inoculation level of $10^{3}-10^{4} \mathrm{CFU} / \mathrm{g}$ for E. coli $\mathrm{O} 157: \mathrm{H} 7$ and of $10^{6}-10^{7} \mathrm{CFU} / \mathrm{g}$ for the other bacteria. $\mathbf{2 a}=$ meat samples kept under refrigeration; $\mathbf{2 b}=$ meat samples kept at room temperature. regardless of the level of contamination. Santos et al., 1995, also observed that E. coli O157:H7 counts remained approximately constant in ground meat kept for 12 days at $9.5^{\circ} \mathrm{C}(20)$. These were less than one log cycle changes in E. coli $\mathrm{O} 157: \mathrm{H} 7$ numbers, whereas indigenous Gram negative bacteria increased their counts from the fourth up to the twelfth day at this temperature.

Greer and Dilts, 1995, observed that spoilage bacteria grew on both fat and lean tissue whereas pathogens grew on fat tissue only (11). Therefore, differences in the affinity for different portions of meat by the microorganisms tested in this study may be the cause for the absence of interference over the multiplication of each other.

The correlation between results of enumeration of $E$. coli $\mathrm{O} 157: \mathrm{H} 7$ using the standard cultural method and the ELISA-type rapid method was high (97.2\%).

Results of the current study suggest that the growth of $E$. coli $\mathrm{O} 157: \mathrm{H} 7$ in artificially contaminated ground beef was not influenced by the presence of different concentrations of nonpathogenic E. coli, Pseudomonas putida or Leuconostoc $\mathrm{sp}$. at refrigeration temperature or at room temperature, indicating that this pathogen is a good competitor. Thus, the low occurrence of $E$. coli O157:H7 in ground beef may not be attributed to competition by other microorganisms.

\section{ACKNOWLEDGMENTS}

The authors thank 3M Microbiology Products, St. Paul, MN, USA, for donation of $3 \mathrm{M}$ Petrifilm ${ }^{\mathrm{TM}}$ Test Kit-HEC, Department of Microbiology, Immunology and Parasitology of Universidade Federal de São Paulo for hybridization assays on E. coli strains and Clinical Laboratory of Hospital Universitário of Universidade de São Paulo for identification of the Pseudomonas putida strain. The authors also thank E.C.P. de Martinis, $\mathrm{PhD}$, for her valuable help.

\section{RESUMO}

\section{Influência da microbiota natural da carne na multiplicação de Escherichia coli O157:H7 em carne bovina moída}

Escherichia coli O157:H7 é um patógeno de origem alimentar de importância crescente, tendo 
sido envolvido em diversos surtos ameaçadores, a maioria deles associada ao consumo de produtos cárneos. Neste estudo foi avaliada a influência de algumas bactérias da microbiota natural da carne crua sobre $E$. coli $\mathrm{O} 157: \mathrm{H} 7$ em amostras de carne bovina moída armazenadas em refrigeração e à temperatura ambiente. As amostras foram inoculadas com diferentes níveis de E. coli $\mathrm{O} 157: \mathrm{H} 7\left(10^{1}, 10^{3}\right.$ e $10^{6}$ $\mathrm{UFC} / \mathrm{g}$ ) e de $E$. coli não patogênica, Pseudomonas putida ou Leuconostoc sp. A multiplicação do patógeno foi monitorada através de metodologia convencional e através de método rápido do tipo ELISA. E. coli não patogênica, Pseudomonas putida e Leuconostoc sp. não exerceram influência sobre a multiplicação de E. coli $\mathrm{O} 157: \mathrm{H} 7$ em carne moída, tanto em refrigeração como à temperatura ambiente. Assim sendo, a baixa ocorrência de E. coli O157:H7 em carne crua não pode ser atribuída a efeitos antagônicos de bactérias de sua microbiota natural.

Palavras-chave: Escherichia coli $\mathrm{O} 157: \mathrm{H} 7$, antagonismo, carne moída

\section{REFERENCES}

1. Armstrong, G.L.; Hollingsworth, J.; Morris, J.G. Emerging foodborne pathogens: Escherichia coli $\mathrm{O} 157: \mathrm{H} 7$ as a model of entry of a new pathogen into the food supply of the developed world. Epidemiol. Rev., 18: 29-51, 1996.

2. Cassin, M.H.; Lammerding, A.M.; Todd, E.C.D.; Ross, W.; McColl, R.S. Quantitative risk assessment for Escherichia coli O157:H7 in ground beef hamburgers. Int. J. Food Microbiol., 41: 21-44, 1998.

3. Cerqueira, A.M.F.; Guth, B.E.C.; Farage, S.; Correa, E.A.; Joaquim, R.M.; Luz, H.S.; Lima, M.P.; Prado, E.H.R.B.; Cruz, C.O.; Andrade, J.R.C. High occurrence of Escherichia coli Shiga toxin (Stx) gene sequence in healthy cattle at Rio de Janeiro, Brazil, using PCR. III International Symposium and Workshop on Shiga Toxin (Verocytotoxin)-Producing Escherichia coli Infections, Baltimore, 1997, p. 28, Summary n. V22/II.

4. Cheng, C.M.; Doyle, M.P.; Luchansky, J.B. Identification of Pseudomonas fluorescens strains isolated from raw pork and chicken that produce siderophores antagonistic towards foodborne pathogens. J. Food Prot., 58: 1340-1344, 1995.

5. Cordovéz, A.; Prado, V.; Maggi, L.; Cordero, J.; Martinez, J.; Misraji, A.; Rios, R.; Soza, G.; Ojeda, A.; Levine, M.M. Enterohemorrhagic Escherichia coli associated with hemolytic-uremic syndrome in Chilean children. J. Clin. Microbiol., 30: 2153-2157, 1992.

6. Doyle, M.P.; Zhao, T.; Meng, J.; Zhao, S. Escherichia coli O157:H7. In: Doyle, M.P.; Beuchat, L.R.; Montville, T.J. (eds). Food microbiology. Fundamentals and frontiers., ASM Press, Washington, 1997, p. 171-191.
7. Ewing, W.H. Edwards and Ewing's Identification of Enterobacteriaceae. 4ed. New York. Elsevier Science, 1986, $536 \mathrm{p}$.

8. Fredrickson, A.G.; Stephanopoulos, G. Microbial competition. Science, 213: 972-979, 1981.

9. Fukushima, H.; Hashizume, T.; Kitani, T. The massive outbreak of E. coli O157 infections by food poisoning among the elementary school children in Sakai, Japan in 1996. III International Symposium and Workshop on Shiga Toxin (Verocytotoxin)-Producing Escherichia coli Infections, Baltimore. 1997, p. 111, Summary n. V6/VII.

10. Gomes, T.A.T.; Ramos, S.R.T.S.; Rodrigues, D.; Rodrigue', D.; Rassi, V.; Toledo, M.R.F.; Vieira, M.A.M.; Gatti, S.V.; Holck, P.; Griffin, P.M. Etiology of acute diarrhea in children 1 to 5 years old in São Paulo, Brazil. 94 General Meeting of the American Society for Microbiology, Las Vegas, 1994, p. 543, Abstracts, C299.

11. Greer, G.G.; Dilts, B.D. Lactic acid inhibition of the growth of spoilage bacteria and cold tolerant pathogens on pork. Int. J. Food Microbiol., 25: 141-151, 1995.

12. Hitchins, A.D.; Hartman, P.A.; Todd, E.C.D. Coliforms Escherichia coli and its toxins. In: Vanderzant, C., Splittstoesser, D.F. (eds). Compendium of methods for the microbiological examination of foods. 3. ed., American Public Health Association, Washington, 1992. p. 325-369.

13. Knight, P. Hemorrhagic E. coli: the danger increases. Am. Soc. Microbiol. News, 59: 247-250, 1993.

14. López, E.L.; Contrini, M.M.; Sanz, M.; Viñas, M.R.; Parma, A.; de Rosa, M.F.; Cleary, T.G. Perspectives on Shiga-like toxin infections in Argentina. J. Food Prot., 60: 1458-1462, 1997.

15. López, E.L.; Diaz, M.; Grinstein, S.; Devoto, S.; Mendilaharzu, F.; Murray, B.E.; Ashkenazi, S.; Rubeglio, E.; Woloj, M.; Vasquez, M.; Turco, M..; Pickering, L.K.; Cleary, T.G. Hemolytic uremic syndrome and diarrhea in Argentine children: the role of Shiga-like toxins. J. Infect. Dis., 160: 469-475, 1989.

16. Maas, R. An improved colony hybridization method with significantly increased sensitivity for detection of single genes. Plasmid, 10: 296-298, 1983.

17. Montville, T.J., Winkowski, K. Biologically based preservation systems and probiotic bacteria. In: Doyle, M.P.; Beuchat; L.R.; Montville, T.J. (eds). Food microbiology. Fundamentals and frontiers. ASM Press, Washington, 1997, p. 557-577.

18. O’Brien, A.D.; Melton, A.R.; Schmitt, C.K.; McKee, M.L.; Batts, M.L.; Griffin, D.E. Profile of Escherichia coli O157:H7 pathogen responsible for hamburger-borne outbreak of hemorrhagic colitis and hemolytic uremic syndrome in Washington. J. Clin. Microbiol., 31: 2799-2801, 1993.

19. Riley, L.W.; Remis, R.S.; Helgerson, S.D.; McGee, H.B.; Wells, J.G.; Davis, B.R.; Hebert, R.J.; Olcott, E.S.; Johnson, L.M.; Hargrett, N.T.; Blake, P.A.; Cohen, M.L. Hemorrhagic colitis associated with a rare Escherichia coli serotype. $N$. Engl. J. Med., 308: 681-685, 1983.

20. Santos, O.; Schwach, T.S.; Zottola, E.A. Competitive growth of enterohemorrhagic Escherichia coli in ground beef at 9,5 $5^{\circ}$ C. J. Food Prot., 58 (Suppl.): 19, 1995.

21. Schillinger, U.; Lücke, F.K. Identification of lactobacilli from meat and meat products. Food Microbiol., 4: 199-208, 1987, 1995. 
22. Suthienkul, O.; Brown, J.E.; Seriwatana, J.; Tienthongdee, S.; Sastravaha, S.; Echeverria, P. Shiga-like toxin producing Escherichia coli in retail meats and cattle in Thailand. Appl. Environ. Microbiol., 56: 1135-1139, 1990.

23. Takeda, T.; Tanimura, M.; Yoshino, K.; Yamagata, K.; Matsuda, E.; Uchida, H.; Ikeda, N. 1997. Questionnairebased clinical aspects of VTEC infection in Japan, 1996. III International Symposium and Workshop on Shiga Toxin (Verocytotoxin)-Producing Escherichia coli Infections, Baltimore, 1997, p. 116, Summary n. V219/VII.

24. Tarr, P.I. Escherichia coli O157:H7: overview of clinical and epidemiological issues. J. Food Prot., 57: 632-636, 1994.
25. Toledo, M.R.F., Fontes, C.F., Trabulsi, L.R. EPM modificação do meio Rugai e Araujo para realização simultânea dos testes de produção de gás a partir da glicose, H2S, urease e triptofano desaminase. Rev. Microbiol., São Paulo, 13: 309-315, 1982a.

26. Toledo, M.R.F., Fontes, C.F., Trabulsi, L.R. MILi - um meio para realização dos testes de motilidade, indol e lisina descarboxilase. Rev. Microbiol., São Paulo, 13: 230-235, 1982b. 